UDC: 339.138

JEL: M310

\title{
REVISITING PERSONALIZATION THROUGH CUSTOMER EXPERIENCE JOURNEY
}

\author{
M. M. Gogua, M. M. Smirnova
}

St. Petersburg State University,

7-9, Universitetskaya nab., St. Petersburg, 199034, Russian Federation

For citation: Gogua M. M., Smirnova M. M. 2020. Revisiting personalization through customer experience journey. Vestnik of Saint Petersburg University. Management 19 (4): 430-460.

https://doi.org/10.21638/11701/spbu08.2020.402

Firms use personalization in order to influence the customer experience through numerous touch points. This influence has positive and negative consequences, which have further strong impact on the customer responses and overall success of the firm's communication with the customer. Personalization and customer experience have the common path of their development and share the fields of applications; however, scientific literature is currently fragmented and analyzes the narrow aspects of either personalization or customer experience. This conceptual article investigates personalization with the focus on the overall customer experience journey and its use for the estimation of customer responses and touch points' utilization. The need for this focus is based on the necessity of the firm to understand customer responses to personalization as well as the factors appearing at pre-purchase, purchase and post-purchase stages of customer decision-making. The theoretical novelty of the paper embraces positive and negative consequences of personalization for identification of future empirical research directions. These conclusions include the impact of anthropomorphization through embedded automated interactive messaging, history-based and group-based recommendation systems as well as the impact of increased touch points and influence of informational vulnerability on customer trust, click-through intentions and reactance. Managerial contributions relate to the suggestions on possible actions required to either enforce particular effects with positive outcomes for customer experience or diminish negative ones in terms of technological facilitation, measurement possibilities and enhancement of information transparency.

Keywords: personalization, customer experience, customer experience journey, marketing touch points, customer behavior, anthropomorphization, personal recommendations, customer information vulnerability.

\section{INTRODUCTION}

Technological changes force firms to actively apply personalization to their marketing efforts to find new ways to deliver value to customers, engage them through improved customer experience and persuade to make a purchase [Kumar, 2018]. Personalization is defined as "a customer-oriented marketing strategy that aims to deliver the right content to the right person at the right time, to maximize immediate and future business opportunities" [Tam, Ho, 2006, p. 867] and as "the matching of advertising content and vendors' services with customers based on their preferences and individual needs" [Turban et al., 2015, p. 418].

(C) St. Petersburg State University, 2020 
Personalization covers numerous and diverse firm-customer cooperation directions, creating additional value for customers and fostering positive customer response. For example, $44 \%$ of customers of North America and Europe and 36\% of customers in Russia confirm they would return to the particular company after a personalized shopping experience and highlight the importance of the personalized offers sent to them [Accenture..., 2018; Global Consumer Insights..., 2019]. Despite these positive results, not all businesses seem to understand the value of personalization or its application. As an outcome, $71 \%$ of customers in the USA are frustrated because their shopping experience is impersonal [The 2017 State of Personalization Report, 2017], and at least 20\% of firms utilizing segmentation (a strategy less individualized than personalization) do not fully understand buyer behavior in the context personalization [Marketing personalization..., 2018].

In order to recognize full potential and effectiveness of personalization, companies need to understand: a) structure of the customer responses; b) structure of relevant factors at different steps of the customer journey; c) the ways these structures enhance the customer experience, which unites both customer responses and customer journey.

The question remains: why does such confusion and difficulty appear in understanding and utilizing personalization by the firms? Such situation of the ambiguity of personalization consequences has roots in the difficulties to control the diverse and numerous touch points utilized (for example, website interacting messaging [Song, Zinkhan, 2008], mobile location-based personal recommendations [Fong, Fang, Luo, 2015], personalized emailing [Chung, Wedel, Rust, 2016], social networks integration [Turban et al., 2015], etc.), which evoke particular customer responses (cognitive, emotional, behavioral, sensorial, and social). These responses are difficult to track and work with, even though they characterize the customer experience, which is enhanced through personalization [Verhoef et al., 2009; Lemon, Verhoef, 2016]. The context of the application of personalization is becoming more complex due to these numerous touch points. Thus, we have to acknowledge that understanding, managing, and controlling numerous touch points in the customer experience along are the main factors that lead to failure or misunderstanding of personalization utilization.

The objective of this study is to investigate potential positive and negative outcomes of personalization on the customer experience by mapping it along the customer journey for identification of directions for further empirical research. To meet this objective, the focus is placed on investigating how personalization components are decomposed based on the customer experience journey and its stages, and, finally, what are potential positive and negative outcomes of personalization from customer and firm perspectives as well as the ways to facilitate or diminish them.

Customer experience is among the intensively discussed topics nowadays [Acquisti, John, Loewenstein, 2012; Hennig-Thurau, Marchand, Marx, 2012; Lemon, Verhoef, 2016; Wedel, Kannan, 2016; Martin, Murphy, 2017; Steinhoff et al., 2019]. In general, customer experience is defined as "a multidimensional construct focusing on a customer's cognitive, emotional, behavioral, sensorial, and social responses to a firm's of- 
ferings during the customer's entire purchase journey" [Lemon, Verhoef, 2016, p. 83]. The definition notes that responses are both partially controllable and uncontrollable by the firms due to the impossibility of prediction of all influencing factors. In order to overcome this ambiguity, firms engage in personalization to establish better customer experience through the touch points.

Even though the literature discusses the aforementioned ideas, they are either narrowed down to the particular segments of the personalization process, examine the separate customer behavior without zooming out to the overall process, or they are customer-centric with limited attention focused on a firm's activities. This research aims to take a more comprehensive approach towards analyzing the process of personalization through the lens of a customer experience journey and thus unites major points of analysis: types and ownership of touch points, types of personalization tools and customer behavior at the purchase stages, thus making it easier for firms to structure or reorganize their implementation of personalization with the respect to possible consequences.

The contribution of the article resides, first, in structuring customer responses to personalization and the consequent customer behavior as a purchase stage-based map of the customer experience; second, in the analysis of co-evolution of customer experience concepts and approaches to personalization with particular attention to the utilization of the tools of the customer experience journey model to the personalization process by structuring its tools based on the touch points; and third, in the identification and development of directions for empirical research.

The research is structured as follows: first, current approaches to personalization are listed in general and through the perspective of the customer experience through customer responses and customer behavior analysis; second, the model of the customer experience journey is tested in relation to personalization; third, the propositions are developed with specific suggestions of their attainability. The article is finalized by the conclusion section, limitations, and discussions.

\section{THEORETICAL BACKGROUND}

This research unites the concepts from two developing areas of research in marketing, personalization and customer experience. These concepts are closely interlinked, with personalization having a strong impact on ways firms build their communication with their new or old customers.

Figure 1 offers an overview of the links between personalization and customer experience.

According to Figure 1, customer experience, if there was a prior engagement with the firm, has an impact on the personalization and consequent customer responses and then results in a new type of customer experience based on the responses evoked. The analysis of the sequence presented in Figure 1 is conducted based on the customer experience model [Lemon, Verhoef, 2016]. 


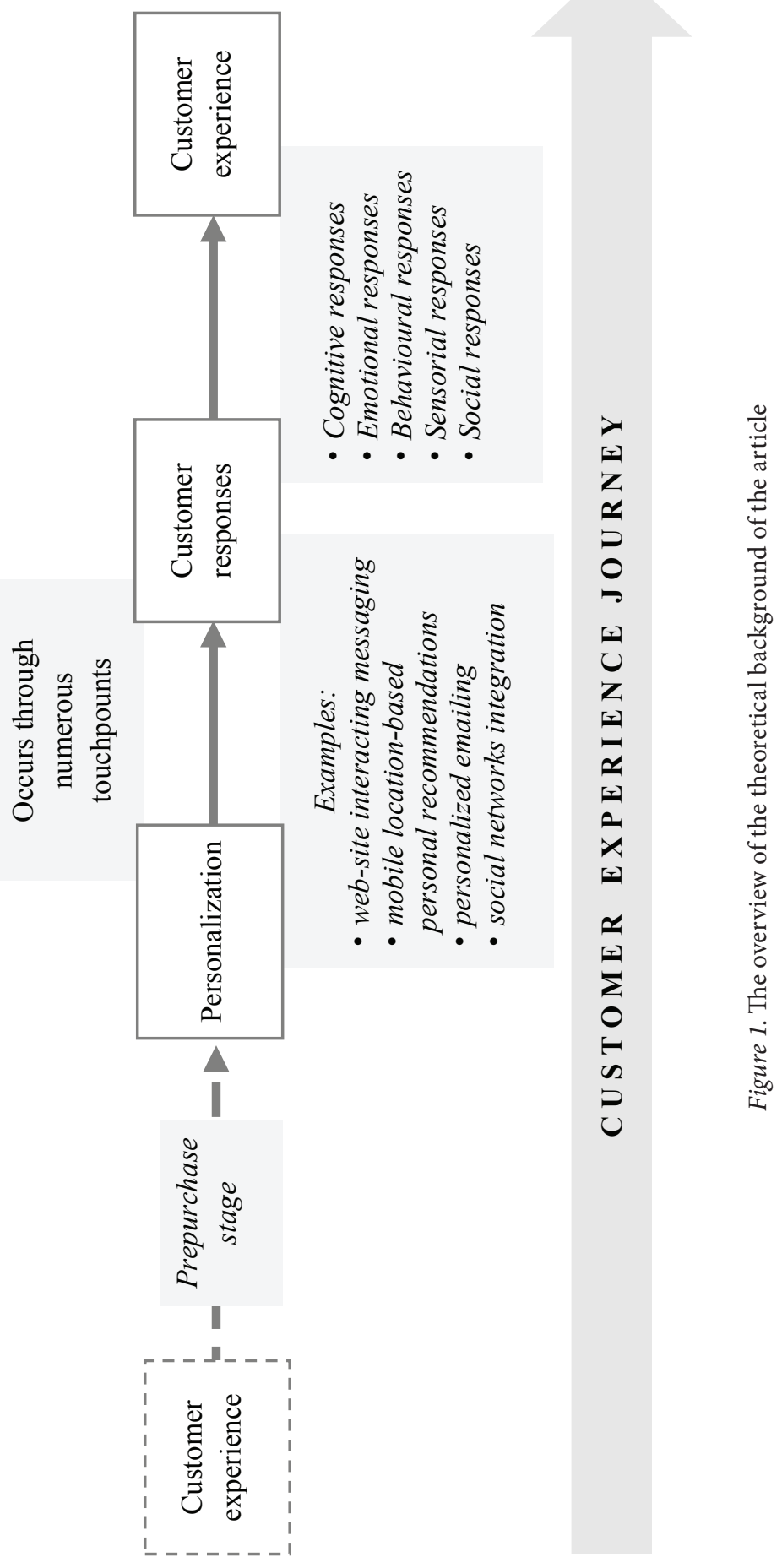


This model allows taking into consideration both firm perspective (personalization tools for offers' delivery through different types of touch points) and customer perspective (in terms of expected customer responses and behavior expected at each stage of the purchasing process, as well as their correspondence with the established personalization tools of the firms). The article further concludes with the set of propositions categorized in positive and negative consequences from customer and firm perspectives with applicable practical suggestions.

Personalization: Current approaches to the definition. Personalization as a concept discussed in marketing science in 1980-1990 was related only to services. It was characterized through the interpersonal relations between the consumer and his/her service providers (at the hairdressers' and beauty salons, car repairs and bank employees) through the perception of gender, age, emotional empathy and, generally, social bias [Iacobucci, Ostrom, 1993; Goodwin, 1996; Mohr, Henson, 1996; Price, Arnould, 1999].

Further, as technology penetrated commercial transactions, personalization retained its role in interpersonal relationships; however, the managers became the third party in customer communication and self-service technology, for example, bank terminal [Giebelhausen et al., 2014]. While the consumer could prefer to interact with the technologically enhanced service provider, the manager introduced personalization for the consumers, who were less motivated to interact directly with the technology. Such consumers wanted to follow their established "script" of behavior (the way consumers "organize their previous experiences in script formations that are used as normative standards to help them understand familiar or new situations" [Giebelhausen et al., 2014, p. 114]), so they could address the frontline employees and get the service from them with the emotional and verbal connection.

Simultaneously, as the communication of firms with consumers started its gradual relocation to websites, personalization emerged into its latest form, such as embedded communication points, instant communication with an e-store (or, supposedly, other platforms or networks with the similarly available feature) [Song, Zinkhan, 2008]. Messages through this channel could be either personal (referring to consumers' inquiry about a delivery delay or incomplete package) or general (information regarding delivery opportunity or pricing specifications). Such an approach also follows earlier traits of personalization; however, it now resides in the technologically created environment. In addition to that, the recommendation systems, specifically in regard to hedonic products, create the resemblance of the communication within the system, which offers something the consumer may prefer [Hennig-Thurau, Marchand, Marx, 2012]. The leading criteria for targeting users for personalized experiences according to marketing representatives of business worldwide are campaign source (43\%), location (39\%), demographics (37\%), products purchased (36\%), clicks (33\%), pages and/or content viewed (32\%), company (27\%), browser (25\%), stage of the customer journey (24\%), and previous visits behavior (23\%) [Marketing personalization..., 2018].

Personalization is closely interlinked with the customer experience because, based on the prediction, it can help in selecting particular tools and mechanisms. Several methods for personalization are identified: pull personalization (a personalized service after the 
customer's explicit request for it, for example, products' customization for individual tastes); passive personalization (personalized information about products or services displayed after the particular customer activities, which still required the customer's action towards it, for example, coupon systems or online recommendations); and push personalization (enhancing the passive personalization by directly providing the customer with the service or product without special request as by, for example, tailoring the movies or the songs playlists to the customers' prior requests) [Wedel, Kannan, 2016].

Anthropomorphization and recommendations as personalization trends. Even though prior customer experience (or its absence) influences the selection of personalized tools, firms may overlook certain positive and negative consequences of personalization. These can be controlled by paying attention to customer responses, consequent behavioral intentions, and steps at the customer journey. Customer responses are becoming of a higher value; further, as the population is becoming more integrated and more accessible, customer's needs are moving to the frontline, and the requests are becoming distinct [Kumar, 2018]. The need to treat such issues as convenience, experiences, social connections and personalization is becoming of the foremost importance for the firms. Global online platforms, such as YouTube, Amazon, Facebook, and Google accumulate large datasets and further produce the offerings to the mobile owners through browsers and mobile applications [Van Heerde, Dinner, Neslin, 2019].

In this article, the existing trends and methods of personalization are divided into those establishing a sense of personal communication with customers for evoking cognitive, emotional, and behavioral responses and those having an impact on the sense of involvement in the group and awareness of their preferences in terms of sensorial and social responses. The first type of methods is established through anthropomorphization and the second one through personal recommendation systems.

Anthropomorphization is defined as "giving human characteristics to artificial objects" [Beltramini, 2019, p. 922], and it can "strengthen brand-consumer relationships" [Heine et al., 2018, p. 484] if the brand utilizes this approach. From this perspective, personalization relates to the use of interacting messaging: chatbots, intelligent agents, conversational agents [Song, Zinkhan, 2008; Trusov, Bucklin, Pauwels, 2009].

Personal recommendations are systems based on displaying of the offers as the selection of products formed on customer's prior purchase history or other similar customers', as well as the average group preference the customer generally belongs to [Coker, Nagpal, 2013; Meyners et al., 2017]. These tools evoke particular customer responses, which further lead to positive or negative customer behavior (for example, decreasing trust [Aguirre et al., 2015; Bleier, Eisenbeiss, 2015], customer reactance to the use of personalization [Bleier, Eisenbeiss, 2015; Martin, Borah, Palmatier, 2017], customer satisfaction [Fitzsimons, Lehmann, 2004; Martin, Borah, Palmatier, 2017], and, overall, customer experience [Falk, Hammerschmidt, Schepers, 2010; Lemon, Verhoef, 2016; Siebert et al., 2020].

Personalization in the context of customer experience research. Historically, research on customer experience has gone through various stages [Lemon, Verhoef, 2016]: customer buying behavior process models (1960-1970s), customer satisfaction and loy- 
alty (1970s), service quality (1980s), relationship marketing (1990s), customer relationship management (CRM) (2000s), customer centricity and customer focus (2000-2010s), and customer engagement (2010s). The last stage that explicitly states the importance of customers' involvement in the cocreation of the experience [Lemon, Verhoef, 2016], which has distinctive implications for the customer responses and data collection to fuel personalization.

Table 1 provides an overview on the development of personalization across four periods, highlighting key authors, focus on stages of customer experience development, and core areas of application. This table excludes the period of 1960-1970s because the term "customer experience" is older than "personalization", therefore, direct mentions of this concept appeared in the 1980s.

Table 1. Historical overview of personalization development

\begin{tabular}{|c|c|c|c|}
\hline Years & $\begin{array}{c}\text { Customer } \\
\text { experience } \\
\text { development } \\
\text { stages }\end{array}$ & $\begin{array}{l}\text { Areas of application and } \\
\text { tools of personalization }\end{array}$ & Author(s) \\
\hline 1 & 2 & 3 & 4 \\
\hline $\begin{array}{l}1980- \\
1990\end{array}$ & $\begin{array}{l}\text { Service } \\
\text { quality } \\
\text { Relationship } \\
\text { marketing }\end{array}$ & $\begin{array}{l}\text { Mail surveys; social biases evaluation; } \\
\text { telephone notifications; response rates } \\
\text { based on surveys anonymity }\end{array}$ & $\begin{array}{l}\text { [Neider, Sugrue, 1983; } \\
\text { Chebat, Picard, 1984; Jobber, } \\
\text { Allen, Oakland, 1985; } \\
\text { Albaum, 1987] }\end{array}$ \\
\hline $\begin{array}{l}1991- \\
2000\end{array}$ & $\begin{array}{l}\text { Customer } \\
\text { relationship } \\
\text { management } \\
(\mathrm{CRM})\end{array}$ & $\begin{array}{l}\text { Telephone interviews; customer } \\
\text { satisfaction evaluation; service } \\
\text { marketing/relationships/quality; } \\
\text { consumer changes; interpersonal } \\
\text { relations (friendliness); technology } \\
\text { inclusion }\end{array}$ & $\begin{array}{l}\text { [Hornik, Zaig, Shadmon, } \\
\text { 1991; Singh, 1991; Grove, } \\
\text { Fisk,1992; Iacobucci, Ostrom, } \\
\text { 1993; Varaldo, Marbach, } \\
\text { 1995; Price, Arnould, 1999; } \\
\text { Bitner, Brown, Meuter, 2000] }\end{array}$ \\
\hline $\begin{array}{l}2001- \\
2010\end{array}$ & $\begin{array}{l}\text { Customer } \\
\text { centricity } \\
\text { and customer } \\
\text { focus }\end{array}$ & $\begin{array}{l}\text { Service quality; customer satisfaction } \\
\text { with technology-based service } \\
\text { encounters; service convenience; } \\
\text { scales development; e-marketing mix; } \\
\text { customization of message style; trust } \\
\text { in service relations; online product } \\
\text { recommendations on consumers' } \\
\text { choice online; emotional components } \\
\text { of transactions; website interactivity } \\
\text { and perceptivity identification; (self-) } \\
\text { customization; individual-level targeting; } \\
\text { buyer monitorization; comparison of } \\
\text { online and offline stores; measurement } \\
\text { of consumer personal features }\end{array}$ & $\begin{array}{l}\text { [Brady, Cronin Jr., 2001; } \\
\text { Berry, Seiders, Grewal, } \\
\text { 2002; Kalyanam, McIntyre, } \\
\text { 2002; Moon, 2002; Rossiter, } \\
\text { 2002; Coulter, Coulter, 2003; } \\
\text { Senecal, Nantel, 2004; Menon, } \\
\text { Dubé, 2007; Song, Zinkhan, } \\
\text { 2008; Ana, Dhar, Zettelmeyer, } \\
\text { 2009; Dong, Manchanda, } \\
\text { Chintagunta, 2009; Kwortnik, } \\
\text { Lynn, Ross, 2009; Zhang, } \\
\text { Wedel, 2009; Sharma, 2010] }\end{array}$ \\
\hline
\end{tabular}




\begin{tabular}{|c|c|c|c|}
\hline 1 & 2 & 3 & 4 \\
\hline $\begin{array}{l}2011- \\
2019\end{array}$ & $\begin{array}{l}\text { Customer } \\
\text { engagement }\end{array}$ & $\begin{array}{l}\text { Customers intention on disclosure; } \\
\text { automated individual-/group } \\
\text { recommenders' influences; customer } \\
\text { responses evaluation; information } \\
\text { disclosure, flow, specificity; brand } \\
\text { perception; technology as benefit or } \\
\text { barrier; consumer decision-making; } \\
\text { value co-creation at market; different } \\
\text { tools of media channels; trust-building } \\
\text { and retention; psychological insights } \\
\text { for consumer behavior understanding; } \\
\text { social networks; data analysis in data- } \\
\text { rich environments; data security and } \\
\text { privacy; (electronic) word of mouth }\end{array}$ & $\begin{array}{l}\text { [Acquisti, John, Loewenstein, } \\
\text { 2012; Hennig-Thurau, } \\
\text { Marchand, Marx, 2012; } \\
\text { Coker, Nagpal, 2013; } \\
\text { Lambrecht, Tucker, 2013; } \\
\text { Liberali, Urban, Hauser, } \\
\text { 2013; Frank, Enkawa, } \\
\text { Schvaneveldt, 2014; } \\
\text { Giebelhausen et al., 2014; } \\
\text { Sonnier, 2014; Aguirre et } \\
\text { al., 2015; Bleier, Eisenbeiss, } \\
\text { 2015; Fong Fang, Luo, 2015; } \\
\text { Schmitt, Joško Brakus, } \\
\text { Zarantonello, 2015; Chung, } \\
\text { Wedel, Rust, 2016; Wedel, } \\
\text { Kannan, 2016; Martin, } \\
\text { Murphy, 2017; Steinhoff et } \\
\text { al., 2019] }\end{array}$ \\
\hline
\end{tabular}

Based on Table 1, it is possible to note that the customer behavior has been changing along with the Internet-mediated environment. While appearing early on, personalization on the individual level was developed through introduction of smartphones, mobile applications, accumulation of large datasets (Big Data), artificial intelligence, and augmented reality, which allowed firms to maintain the feeling of personal relationships with each consumer via better data collection and accumulation.

However, the process of maintaining continuous relationships with each consumer is quite ambiguous: firms keep evaluating customer satisfaction and customer experience; however, it becomes more difficult to understand why an individual consumer terminates the communications with a particular brand. In this regards, personalization introduced through webpages and mobile apps enables firms to offering of building positive relationships between customers and firms [Kim, Wang, Malthouse, 2015] and deepens customer relationships [Aguirre et al., 2015] as well as to maximize an immediate and future business opportunities [Lemon, Verhoef, 2016].

Core customer-related concepts along the personalization process. As personalization is largely based on customer data collected through numerous touch points that are brand-owned, customer-owned, partner-owned and social (external) [Lemon, Verhoef, 2016], it requires a firm to be present at different media channels and platforms (including social networks, websites, mobile phones, applications, wearable technology (ex. smartwatches and bracelets)) [Kannan, Li, 2017]. This data accumulation, on the one hand, facilitates firms' abilities to provide better personalization to the customers 
and store and structure available data [Turban et al., 2015; Kannan, Li, 2017]; however, on the other hand, it also leads to the informational vulnerability of customers and privacy concerns [Aguirre et al., 2015; Bleier, Eisenbeiss, 2015; Wedel, Kannan, 2016; Martin, Borah, Palmatier, 2017; Kim, Wang, Malthouse, 2015; Kim, Barasz, John, 2019]. Therefore, there is a strong connection with the customer experience and, consequently, the customer experience journey.

Structuring the customer reactions as the customer-related concepts along the personalization process. A suggested structure of customer responses, as well as stages of personalization process along the customer journey, is presented in Figure 2, which also shows the existing customer-related concepts that influence the customers' potential cognitive, emotional, behavioral, sensorial, and social responses based on their impact discussed at each identified customer journey step.

The roots of customers' responses come from the idea of experiential marketing, where sensorial (sensory) experiences are based on the customers' senses, cognitive (also referred to as creative cognitive) on the thinking of the customers, emotional (also referred to as affective) on the feelings of the customers, behavioral relate to the cultural and personal antecedents of customer's specific ways of acting and lifestyle, and social responses are based on the social identity experiences resulting from a customer's relation with the particular reference group [Schmitt, 1999; Verhoef et al., 2009; De Keyser et al., 2015]. Measurement of these responses differs based on their potential applications, for example, to the brand experience [Schmitt, Joško Brakus, Zarantonello, 2015], to retailing in general [Grewal, Levy, Kumar, 2009], to customer data collection in general [De Keyser et al., 2015]. Technology itself can be considered as an experience [McCarthy, Wright, 2004; Lemon, Verhoef, 2016] and technology utilization consequences can be defined by aforementioned types of customer responses for determination of further customer-related concepts in customer behavior patterns.

In order to identify the concepts, related to potential customer response, a systematic overview of personalization-related articles in leading marketing journals (ABS journal ranking, level 4) was conducted. The initial search resulted in 127 articles; however, after the manual selection, we selected 29 articles with the focus on customer-related concepts in the technologically mediated environment.

Figure 2 consists of three components: customer-related concepts extracted from the selected articles on the vertical axis and the personalization process on the horizontal axis. The customer-related concepts are further diversified into two categories: broad category related to the actual customer responses and customer-related instruments, which are discussed in the selected articles but refer more to the mechanics of personalization rather than the response. In line with the extant research, the distribution of the concepts considers the main stages of the customer journey - prepurchase, purchase and postpurchase ${ }^{1}$. Thus, it is possible to follow the development of the customer-related

1 As the term "postpurchase" has other spelling variants, in this article we follow the style of [Lemon, Verhoef, 2016]. 


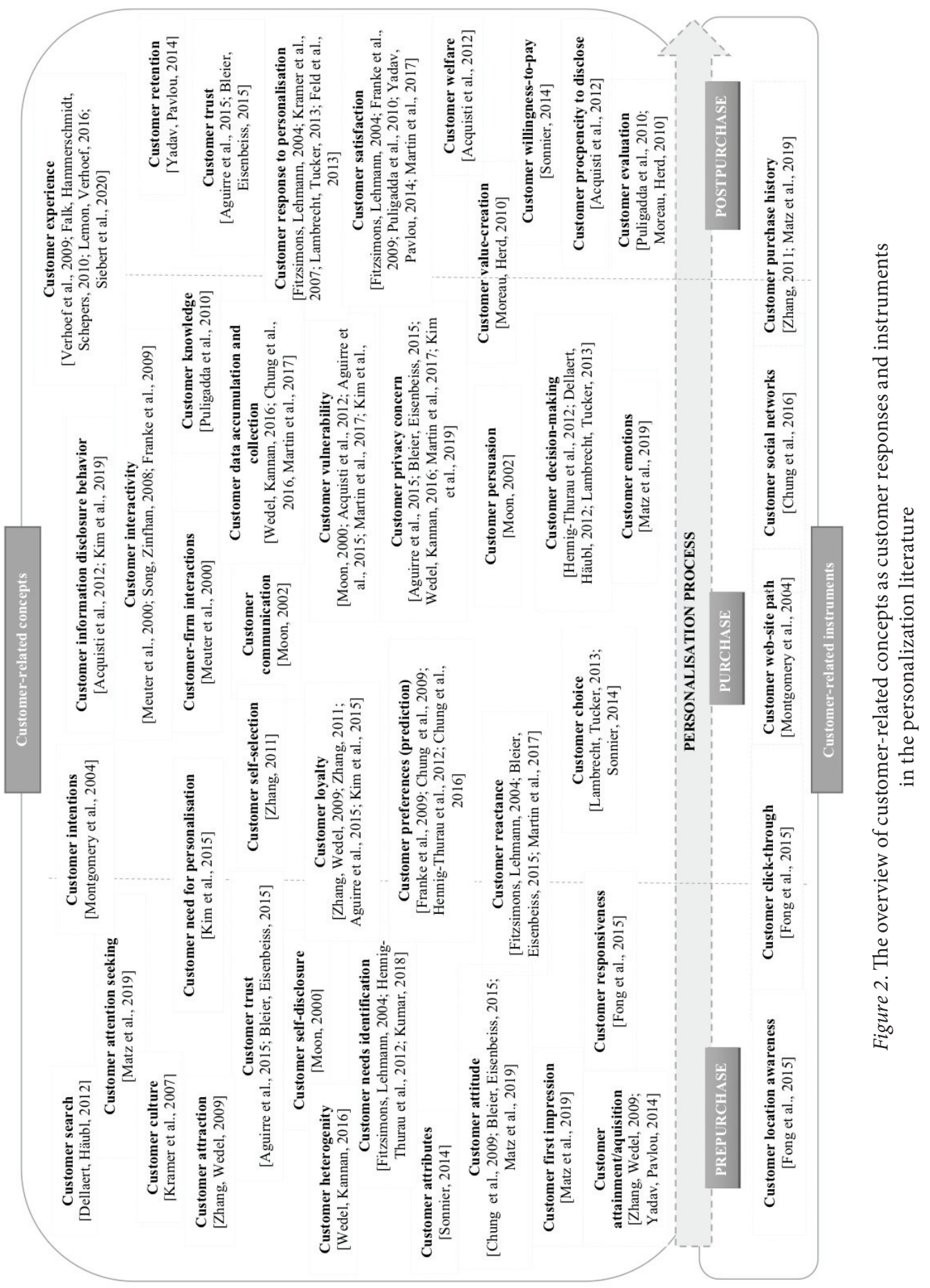


concepts and instruments via the prepurchase, purchase and post-purchase stages of the customer experience journey (Figure 2). This representation of the personalization process along the stages of the customer journey on the horizontal axis is central for understanding the figure, while along the vertical axis all concepts have equal weights. As placement of personalization concepts along the stages of customer journey is based on analyzed articles, the same concept might appear associated with different stages if this corresponds with the findings from the analyzed sources.

An additional description of the results of systematic literature review is presented in Appendix. The Appendix contains a comprehensive description of articles, including their focus on personalization applications and major customer-related concepts discussed. Further, the table allows categorizing customers' responses into the cognitive, emotional, behavioral, sensorial and social. This table also includes the distribution of articles' focus on customer response analysis in terms of the purchase stages (prepurchase, purchase, and post-purchase). Finally, in order to fully extract all concepts for estimation of the customer experience, the ownership of touch points is indicated. Appendix presents current trends in personalization, customer responses, and their application to customer experience, whereas the customer-related concepts and distribution of the components of the customer experience journey set the foundations and focus for the development of the map of personalization use in the literature.

Customer information vulnerability. Customer vulnerability is a broadly discussed topic [Chung, Rust, Wedel, 2009; Janakiraman, Lim, Rishika, 2018; Kim, Barasz, John, 2019] that shapes customers' cognitive, social, and behavioral responses to a firm's actions, including information disclosure. Even though customers and retailers recognize the benefits of personalization, the personalization paradox occurs. It implies that consumers may recognize how much data and information retailers have about them and begin to worry about their privacy [Aguirre et al., 2015].

A broad type of customer data vulnerability is data access vulnerability, which is defined as a firm access to consumers' personal data. This type of data vulnerability makes consumers more conscious regarding the information they are placing on websites (or other media means), the level of their trust to the firm and general intentions towards the disclosure of sensitive information. In addition, the level of reciprocity (or the level at which they think the firm is honest with them as well) plays an important role. Even though it is suggested that firms need to control data management policies and ensure transparency, the balance is still difficult to maintain. Any error may lead to the negative word of mouth [Janakiraman, Lim, Rishika, 2018], which may further lead to the feeling of vulnerability of the consumer [Martin, Borah, Palmatier, 2017].

The negative consequences of customer data vulnerability could be solved by offering the information disclosure, meaning that consumers can agree to proceed to a website or other tool to access an online store, and it will be acknowledged that firms may use information about their movement and additional information [Kim, Barasz, John, 2019]. However, firms may find it difficult to understand how to extract the required information from the accumulated Big Data, as well as how to add the automation to ob- 
tain "real-time" execution [Kannan, Li, 2017]. In this case, it is suggested for the firms to find appropriate levels of data collection, its sources, and a particular level of granularity [Wedel, Kannan, 2016].

The fact that all types of data access vulnerability appear at different stages of the customer journey confirms the fact of applicability for selecting the model for the understanding of personalization. This association with the customer experience journey can help overcome fragmentation in defining personalization and improving its understanding.

\section{LINKING PERSONALIZATION AND CUSTOMER EXPERIENCE THROUGH THE CUSTOMER EXPERIENCE JOURNEY}

Personalization is recognized as both the marketing customer-oriented strategy of delivering the right content to the right person for firm's business opportunities maximization [Tam, Ho, 2006] and a set of tools for customer needs and a firm's offering matching [Turban et al., 2015]. Adjusting understanding of personalization to the customer experience journey can help to better understand personalization-driven customer responses, as responses to both strategic actions and applied personalization tools. Three stages of customer journey are considered: prepurchase stage, purchase stage and postpurchase stage [Lemon, Verhoef, 2016].

At each stage of the customer experience journey, the customer engages in different types of behavior: first, there is a need recognition, consideration and search; second, their choice, ordering and payment happens; third, the customer faces consumption, usage, engagement and service requests. Each stage, however, cannot be considered in isolation: each stage is influenced by the previous experience, which in its turn has an impact on customers' future experiences.

All three stages contain numerous touch points, which can be classified into brandowned, partner-owned, customer-owned and social/external [Lemon, Verhoef, 2016]. Finally, it is important to consider the angle of customer vulnerability, including for example, data access vulnerability as the access of a firm to consumer's personal data. This type of data vulnerability makes a customer more conscious regarding the information they are placing at a websites (or other media means), the level of their trust to the brand, and general intentions towards the disclosure of sensitive information. In addition to that, the level of reciprocity (or the level at which a customer thinks a firm is honest with them as well), plays an important role.

Customer experience journey model application in the context of personalization. Customer experience in the context of personalization helps to evaluate the success of its directions through the analysis of customer responses to them and consequent customer behavior, the spread of personalization applications over the purchase stages, and touch points. This evaluation further allows one to narrow this study down to five issues in personalization with positive and negative consequences for both customers and firms.

Purchase stages and touch points distribution within personalization. At the stage of prepurchase, brand-owned touch points are personalized through the tools, which sim- 
plify the search for a particular product because the automated system can track each particular consumer's behaviour and pull personalization and mass-personalization, which relates to the personalization in a broad sense when the tastes are averaged. In addition, embedded interacting messaging on an e-platform directly integrates potential customers into the cooperation with a firm and receive the best treatment and product by the initiation of direct communication through anthropomorphization. Customers in turn own media presence, which is the source of information for firms, and customers and firms can communicate through social channels (assuming the firm also has at least one). External and social touch points are presenting brand-related publics/pages in social media, not controlled or initiated by the firm, and positive word of mouth in the community.

At the stage of purchase, a firm can offer a technologically-enhanced offer based on a search pattern as well as the transparency and security of the transaction. A customer in turn is able to use the means for transactions (cards, online banks), and they have trust in the brand. Finally, the word of mouth in this case can influence the ordering decision-making and data security perception. In addition, the choice of delivery could also be grounds of personalization for the consumer.

Postpurchase touch point is the most crucial one because it is the stage of consumers' compliant or satisfaction and their further feedback both to brand and to the online community through word of mouth or electronic word of mouth as an external/social touch point. Behaviour at this stage is presented by consumption, usage, engagement, and service requests. Once the purchase is concluded, a brand can, through owned touch points, offer the consumers customer service with a more personalized approach, for example, anthropomorphization. Further, it can use passive- and segment-level personalization, when the consumer is placed in a group of people with the similar tastes and the product is offered through these filters and, more directly, through push and individual-level personalization. Customer-owned touch points then relate to the social media, through which they co-create the value for a brand and product, either positively through good feedback or vice versa.

Derivation of positive and negative consequences of personalization within the customer experience journey and related suggestions. Regardless of personalization benefits, it is also important to discuss negative points for such a seemingly good strategy. Table 2 provides an overview of general positive and negative outcomes of personalization for firms and customers.

Thus, positive outcomes of personalization relate to the anthropomorphization through embedded automated interacting messaging, recommendation systems based on customer's prior actions, transactions and purchase history, and group-based recommendation systems based on context and collaborative filtering. Their positive impact on firms relates to the data accumulation facilitation, customer experience creation support and communication automatization. Moreover, customers benefit from the reduction of time spent on information search, simplification of the decision-making process, and perceptions of social inclusion. 


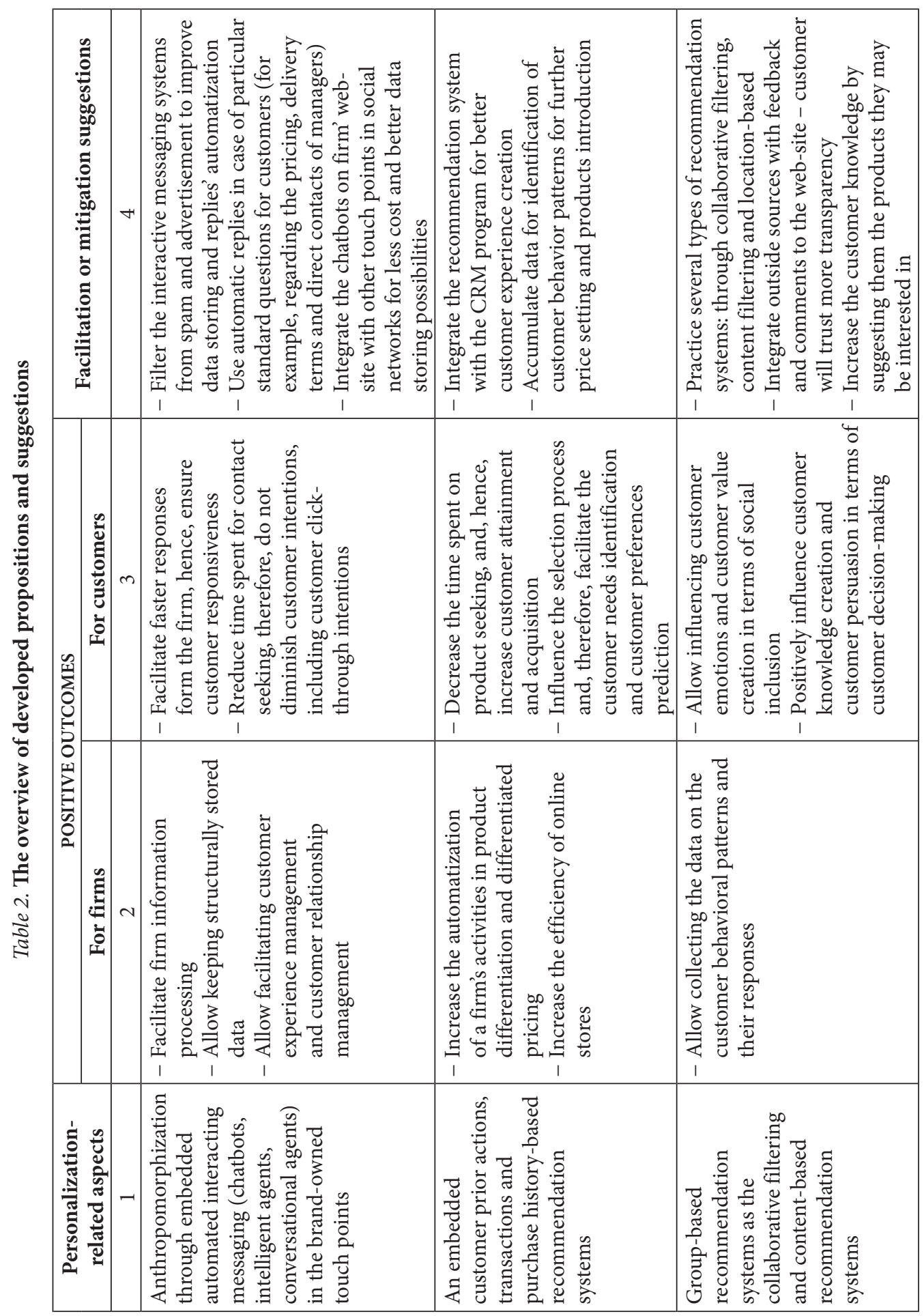




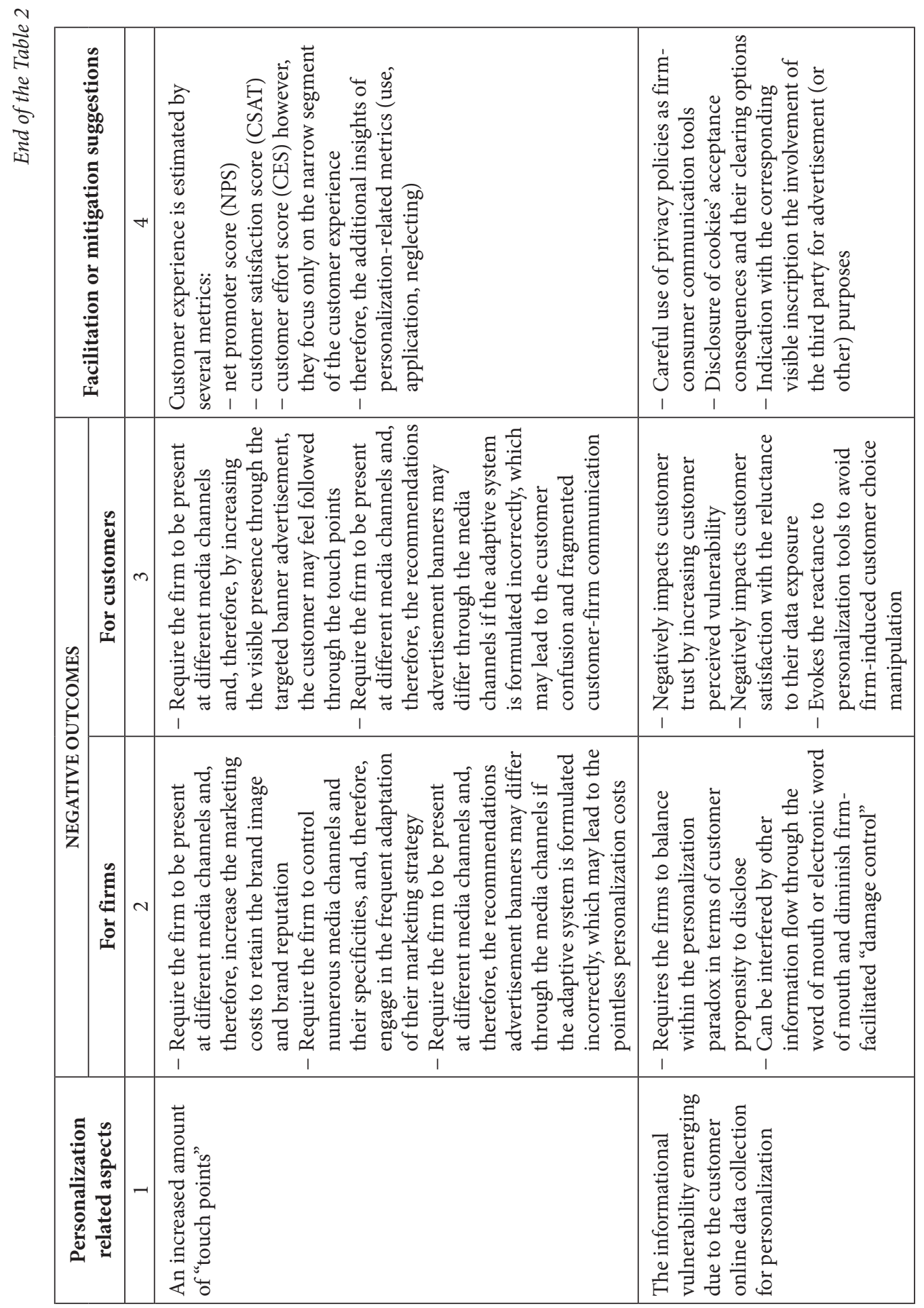


These aspects are facilitated via improvement of automatization facilitation, clarification of algorithms for communication in terms of standard replies for pricing, delivery and contact information, and improvement of CRM integration for feedback collection and enhanced customer communication.

Despite the positive aspects, personalization is accompanied by certain negative consequences. An increased amount of touch points interferes with the communication between customer and firm, making it more difficult to retain a firm's image and firm reputation by increased costs for channels' control and uncontrolled personalization investments. Customers struggle from the sense of being followed and feeling of confusion in the case of a firms' excessive presence in different channels and inconsistency of delivery of offers through the variation of advertisements or recommendations displayed. Data accumulation for personalization facilitation may lead to the informational vulnerability of the customer, leading to the personalization paradox and uncontrolled electronic word-of-mouth, the reduction of customer trust and perceived vulnerability, and the feeling of restricted of freedom of choice. Mitigation of these aspects relates to better measurement of personalization components and transparency increase through the disclosure in privacy policies and probable third parties' involvement.

It is fairly difficult for a firm to properly balance positive and negative sides of such powerful strategy as personalization. However, this strategy is useful because of its effectiveness and its applicability to the new technological environment. Such ambiguous consequences have theoretical foundations to be considered as the potential directions for future empirical research to fill the identified gaps in the application of customer experience journey to the context of personalization.

\section{DISCUSSION}

In this article the relationship between consumer experience development and personalization was identified, a unifying model of personalization within the framework of customer experience journey was developed, and its positive and negative consequences of it were discussed. These consequences could be considered as the directions for further empirical research in order to fill in the identified gaps and contribute to further development in both theory and practice.

Personalization has been interlinked with the customer experience development based on extant research. During the period from 2011 to 2020, research on the customer experience has been related to customer engagement and thus with the increased importance of personalization. Personalization allows one to contact the customers directly through developed media channels and tools, get objective and full information on consumer behaviours, and offer customers the easiest and the most beneficial ways to engage and co-create value.

As the theoretical section covered numerous ideas and concepts and their intersections, Figure 3 aims at offering an overview of the article: its theoretical background, a new context for the existing model, and resulting outputs. 


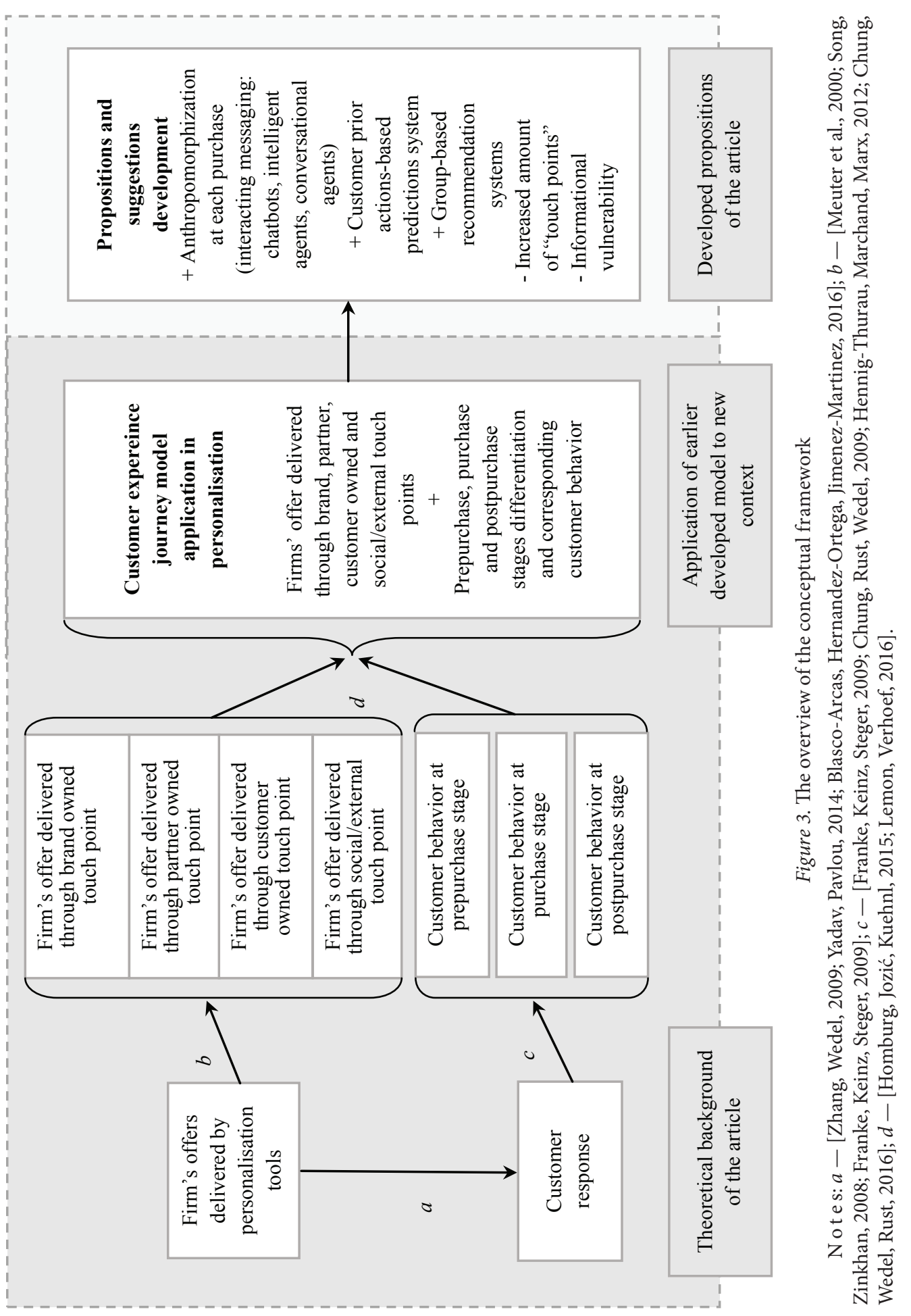


Figure 3 provides an overview of the intended contribution of this conceptual study. The theoretical framework unites several research flows, leads to the formation of the multicomponent concept of customer experience, and therefore allows for the utilization of selected tools of the customer experience model to be used in the new context; it further draws upon the propositions and the suggestions of their facilitation (as the proposition relates to the positive consequences) and mitigation (as the consequences are expected to be negative). Based on the theoretical overview, it is possible to state that personalization plays an important role in the customer experience journey at each stage of prepurchase, purchase and postpurchase. As it is presented at the model on Figure 3, all possible touch points are associated with the personalization and its traits for beneficial outcomes, which are influenced by previous and future experience as well as by the behavioural intentions of the consumer at each particular step.

We highlight both positive and negative consequences of personalization and claim they are expectedly different from the points of view of firms and consumers. Positive outcomes are suggested to be correlated with the ease of use of particular websites, service requests, offerings of recommendations and communication for reduction of time and resources costs; however, the threat of informational vulnerability and data security breach is unavoidable as well as the increased complexity due to the increased amount of touch points and media channel communication.

Contributions of this conceptual study are both theoretical and managerial. Theoretically, the article presents the structured analysis of customer responses and the consequent behavior as outcomes of personalization as a purchase stage-based map of customer experience and utilization of the customer experience journey model to the personalization process by structuring its tools based on the touch points.

It is difficult to argue with the fact that personalization is vital in current business activities; further, it poses various interesting theoretical and practical questions for additional research. Nevertheless, the discussion of positive and negative outcomes is important for both academicians and practitioners. Due to the complexity of personalization, neatly presented frameworks and suggested approaches from different personalization tools do not necessarily lead to the clarity of how to actually apply personalization in practice.

Data security and vulnerability are the problems, which are not expected to be avoided; hence, practitioners are faced with more local tasks of highlighting their risks and benefits. This question could be further addressed in more industry or product-specific research papers. In addition, this paper is limited to B2C commercial transactions and communication; adding different types of business operations will reveal additional interesting points (and the point of the partner-owned touch point can be added back to the customer experience journey model at each stage of the purchase process).

\section{CONCLUSIONS}

The evolution of personalization along the customer experience is evident, however, not specifically discussed in the academic literature. Utilisation of the customer experience model in the new context offers a new perspective of customer behaviour. 
According to the statistics, customers and firms enjoy the benefits of personalization through the facilitation of communication on an individual level and establishment of customer trust and engagement. However, these benefits are mitigated by the perceived vulnerability of customers in terms of increasing privacy concerns regarding data collection and untransparent information disclosed as well as interlinked touch points and difficulties of their measurement and management. These points form customer experience in terms of customer responses, touch point ownerships, and purchase stages; therefore, this article continues ideas of current fragmented literature insights and applies the model of customer experience journey to the new context, the context of personalization. This application is justified by the creation of the sequence of stages of the historical development of personalization with close links to customer experience (Table 1) and by identification of customer responses to the use of personalization (Figure 2). The aforementioned steps allow us to develop the map of positive and negative consequences of personalization (Table 2), which further leads to the identification of potential further empirical research.

The findings of this research are presented as a set of propositions, which refers to the most central personalization-related issues influencing the customer experience. Introduction of anthropomorphization through interacting messaging (chatbots, conversational, and intelligent agents) and several types of recommendation systems allow firms and customers to experience positive consequences, such as structuring and better processing information, managing the touch points and customer relationships and customer experience, and predicting the customers' responses and intentions. However, these consequences are mitigated by the difficulties related to the increasing amounts of touch points and their specificities as well as customers' increased informational vulnerability as they need more time to develop trust to a firm's online presence, they try to protect their data by reducing informational disclosure, and they expect their choices to be manipulated.

Based on the analysis of customer responses to a firm's offerings and consequent customer-related concepts at purchase steps as well as the most utilized personalization tools, this research identifies positive and negative consequences of personalization both for customers and firms as well as the facilitation and mitigation suggestions, which creates further direction for future empirical research. Therefore, this study contributes to the theory on personalization and customer experience by suggesting propositions for future empirical research. In addition to that, we structure customer responses to personalization and the consequent customer behavior as a purchase stage-based map of customer experience and analyses of the co-evolution of customer experience concepts; we also include approaches to personalization with particular attention to the tools' utilization of the customer experience journey model to the personalization process by structuring its tools based on the touch points. Managerial implications relate to the untangling of complex processes of personalization and accompanying customer experience into practically implementable actions, leading to the creation of a checklist to apply to a firm's operation or estimate potential actions; in addition, firms obtain understanding of the possible customer responses and potential ways to evoke them. 


\section{References}

Accenture Interactive Pulse Check 2018. Making it personal. 2018. Accenture. URL: https://www. accenture.com/_acnmedia/PDF-77/Accenture-Pulse-Survey.pdf (accessed: 20.08.2020).

Acquisti A., John L. K., Loewenstein G. 2012. The impact of relative standards on the propensity to disclose. Journal of Marketing Research 49 (2): 160-174.

Aguirre E., Mahr D., Grewal D., de Ruyter K., Wetzel M. 2015. Unravelling the personalization paradox: The effect of information collection and trust-building strategies on online advertisement effectiveness. Journal of Retailing 91 (1): 34-49.

Albaum G. 1987. Do source and anonymity affect mail survey results? Journal of the Academy of Marketing Science 15 (3): 74-81.

Ana V., Dhar R., Zettelmeyer F. 2009. Contingent response to self-customization procedures: Implications for decision satisfaction and choice. Journal of Marketing Research 46 (6): 754-763.

Beltramini E. 2019. Evil and roboethics in management studies. Artificial Intelligence and Society 34 (2): 921-929.

Berry L. L., Seiders K., Grewal D. 2002. Understanding service convenience. Journal of Marketing 66 (3): 1-17.

Blasco-Arcas L., Hernandez-Ortega B. I., Jimenez-Martinez J. 2016. Engagement platforms: The role of emotions in fostering customer engagement and brand image in interactive media. Journal of Service Theory and Practice 26 (5): 559-589.

Bitner M. J., Brown S. W., Meuter M. L. 2000. Technology infusion in service encounters. Journal of the Academy of Marketing Science 28 (1): 138-149.

Bleier A., Eisenbeiss M. 2015. Personalized online advertising effectiveness: The interplay of what, when, and where. Marketing Science 34 (5): 669-688.

Brady M. K., Cronin J. J., Jr. 2001. Some new thoughts on conceptualizing perceived service quality: A hierarchical approach. Journal of Marketing 65 (3): 34-49.

Chebat J.-C., Picard J. 1984. The prenotification of respondents in mailed questionnaire surveys as a source of sample bias. International Journal of Research in Marketing 1 (3): 235-239.

Chung T. S., Rust R. T., Wedel M. 2009. My mobile music: An adaptive personalization system for digital audio players. Marketing Science 28 (1): 52-68.

Chung T. S., Wedel M., Rust R. T. 2016. Adaptive personalization using social networks. Journal of the Academy of Marketing Science 44 (1): 66-87.

Coker B., Nagpal A. 2013. Building-up versus paring-down: Consumer responses to recommendations when customizing. Journal of Retailing 89 (2): 190-206.

Coulter K. S., Coulter R. A. 2003. The effects of industry knowledge on the development of trust in service relationships. International Journal of Research in Marketing 20 (1): 31-43.

De Keyser A., Lemon K. N., Keiningham T., Klaus Ph. 2015. A Framework for Understanding and Managing the Customer Experience. Working Paper No. 15-121. Cambridge, MA: Marketing Science Institute.

Dellaert B. G. C., Häubl G. 2012. Searching in choice mode: Consumer decision processes in product search with recommendations. Journal of Marketing Research 49 (2): 277-288.

Dong X., Manchanda P., Chintagunta P. K. 2009. Quantifying the benefits of individual-level targeting in the presence of firm strategic behavior. Journal of Marketing Research 46 (2): 207-221.

Falk T., Hammerschmidt M., Schepers J. J. L. 2010. The service quality-satisfaction link revisited: Exploring asymmetries and dynamics. Journal of the Academy of Marketing Science 38 (3): 288-302.

Feld S., Frenzen H., Krafft M., Peters K., Verhoef P. C. 2013. The effects of mailing design characteristics on direct mail campaign performance. International Journal of Research in Marketing 30 (2): 143-159.

Fitzsimons G. J., Lehmann D. R. 2004. Reactance to recommendations: When unsolicited advice yields contrary responses. Marketing Science 23 (1): 82-94. 
Fong N. M., Fang Z., Luo X. 2015. Geoconquesting: Competitive locational targeting of mobile promotions. Journal of Marketing Research 52 (5): 726-735.

Frank B., Enkawa T., Schvaneveldt S. J. 2014. How do the success factors driving repurchase intent differ between male and female customers? Journal of the Academy of Marketing Science 42 (2): 171-185.

Franke N., Keinz P., Steger C. J. 2009. Testing the value of customization: When do customers really prefer products tailored to their preferences? Journal of Marketing 73 (5): 103-121.

Giebelhausen M., Robinson S. G., Sirianni N. J., Brady M. K. 2014. Touch versus tech: When technology functions as a barrier or a benefit to service encounters. Journal of Marketing 78 (4): 113-124.

Global Consumer Insights Survey 2019. 2019. PricewaterhouseCoopers International Limited. URL: https://www.pwc.ru/en/retail-consumer/publications/gcis-2019-en.pdf (accessed: 20.08.2020).

Goodwin C. 1996. Communality as a dimension of service relationships. Journal of Consumer Psychology 5 (4): 387-415.

Grewal D., Levy M., Kumar V. 2009. Customer experience management in retailing: An organizing framework. Journal of Retailing 85 (1): 1-14.

Grove S. J., Fisk R. P. 1992. Observational data collection methods for services marketing: An overview. Journal of the Academy of Marketing Science 20 (3): 217-224.

Heine K., Atwal G., Crener-Ricard S., Phan M. 2018. Personality-driven luxury brand management. Journal of Brand Management 25 (5): 474-487.

Hennig-Thurau T., Marchand A., Marx P. 2012. Can automated group recommender systems help consumers make better choices? Journal of Marketing 76 (5): 89-109.

Homburg C., Jozić D., Kuehnl C. 2015. Customer experience management: Toward implementing an evolving marketing concept. Journal of the Academy of Marketing Science 45 (1): 377-401.

Hornik J., Zaig T., Shadmon D. 1991. Increasing compliance in costly telephone interviews: A test of four inducement techniques International. Journal of Research in Marketing 8 (2): 147-153.

Iacobucci D., Ostrom A. 1993. Gender differences in the impact of core and relational aspects of services on the evaluation of service encounters. Journal of Consumer Psychology 2 (3): 257-286.

Janakiraman R., Lim J. H., Rishika R. 2018. The effect of a data breach announcement on customer behavior: Evidence from a multichannel retailer. Journal of Marketing 82 (2): 85-105.

Jobber D., Allen N., Oakland J. 1985. The impact of telephone notification strategies on response to an industrial mail survey. International Journal of Research in Marketing 2 (4): 291-296.

Kalyanam K., McIntyre S. 2002. The e-marketing mix: A contribution of the e-tailing wars. Journal of the Academy of Marketing Science 30 (4): 487-499.

Kannan P. K., Li H. 2017. Digital marketing: A framework, review and research agenda. International Journal of Research in Marketing 34 (1): 22-45.

Kim S. J., Wang R. J. H., Malthouse E. C. 2015. The effects of adopting and using a brand's mobile application on customers' subsequent purchase behavior. Journal of Interactive Marketing 31: 28-41.

Kim T., Barasz K., John L. K. 2019. Why am I seeing this ad? The effect of ad transparency on ad effectiveness. Journal of Consumer Research 45 (5): 906-932.

Kramer T., Spolter-Weisfeld S., Thakkar M. 2007. The effect of cultural orientation on consumer responses to personalization. Marketing Science 26 (2): 246-258.

Kumar V. 2018. Transformative marketing: The next 20 years. Journal of Marketing 82 (4): 1-12.

Kwortnik R. J., Lynn W. M., Ross W. T. 2009. Buyer monitoring: A means to insure personalized service. Journal of Marketing Research 46 (5): 573-583.

Lambrecht A., Tucker C. 2013. When does retargeting work? Information specificity in online advertising. Journal of Marketing Research 50 (5): 561-576.

Lemon K. N., Verhoef P. C. 2016. Understanding customer experience throughout the customer journey. Journal of Marketing 80 (6): 69-96.

Liberali G., Urban G. L., Hauser J. R. 2013. Competitive information, trust, brand consideration and sales: Two field experiments. International Journal of Research in Marketing 30 (2): 101-113. 
Marketing personalization - Statistics and facts. 2018. Statista. URL: https:/www.statista.com/ topics/4481/personalized-marketing/ (accessed: 20.08.2020).

Martin K. D., Murphy P. E. 2017. The role of data privacy in marketing. Journal of the Academy of Marketing Science 45 (2): 135-155.

Martin K. D., Borah A., Palmatier R. W. 2017. Data privacy: Effects on customer and firm performance. Journal of Marketing 81 (1): 36-58.

Matz S. C., Segalin C., Stillwell D., Müller S. R., Bos M. W. 2019. Predicting the personal appeal of marketing images using computational methods. Journal of Consumer Psychology 29 (3): 370-390.

McCarthy J., Wright P. 2004. Technology as Experience. Cambridge, MA: MIT Press.

Menon K., Dubé L. 2007. The effect of emotional provider support on angry versus anxious consumers. International Journal of Research in Marketing 24 (3): 268-275.

Meyners J., Barrot C., Becker J. U., Goldenberg J. 2017. The role of mere closeness: How geographic proximity affects social influence. Journal of Marketing 81 (5): 49-66.

Meuter M. L., Ostrom A. L., Roundtree R. I., Bitner M. J. 2000. Self-service technologies: Understanding customer satisfaction with technology-based service encounters. Journal of Marketing 64 (3): $50-64$.

Moon Y. 2000. Intimate exchanges: Using computers to elicit self-disclosure from consumers. Journal of Consumer Research 26 (4): 323-339.

Moon Y. 2002. Personalization and personality: Some effects of customizing message style based on consumer personality. Journal of Consumer Psychology 12 (4): 313-325.

Mohr L. A., Henson S. W. 1996. Impact of employee gender and job congruency on customer satisfaction. Journal of Consumer Psychology 5 (2): 161-187.

Moreau C. P., Herd K. B. 2010. To each his own? How comparisons with others influence consumers' evaluations of their self-designed products. Journal of Consumer Research 36 (5): 806-819.

Montgomery A. L., Li S., Srinivasan K., Liechty J. C. 2004. Modeling online browsing and path analysis using clickstream data. Marketing Science 23 (4): 579-595.

Neider L. L., Sugrue P. K. 1983. Addressing procedures as a mail survey response inducement technique. Journal of the Academy of Marketing Science 11 (4): 455-460.

Price L. L., Arnould E. J. 1999. Commercial friendships: Service provider-client relationships in context. Journal of Marketing 63 (4): 38-56.

Puligadda S., Grewal R., Rangaswamy A., Kardes F. R. 2010. The role of idiosyncratic attribute evaluation in mass customization. Journal of Consumer Psychology 20 (3): 369-380.

Rossiter J. R. 2002. The C-OAR-SE procedure for scale development in marketing. International Journal of Research in Marketing 19 (4): 305-335.

Schmitt B. 1999. Experiential marketing. Journal of Marketing Management 15 (1): 53-67.

Schmitt B., Joško Brakus J., Zarantonello L. 2015. From experiential psychology to consumer experience. Journal of Consumer Psychology 25 (1): 166-171.

Senecal S., Nantel J. 2004. The influence of online product recommendations on consumers' online choices. Journal of Retailing 80 (2): 159-169.

The 2017 State of Personalization Report. 2017. Segment. URL: http://grow.segment.com/Segment2017-Personalization-Report.pdf (accessed: 20.08.2020).

Sharma P. 2010. Measuring personal cultural orientations: Scale development and validation Journal of the Academy of Marketing Science 38 (6): 787-806.

Siebert M., Gaba J. F., Caquelin L., Gouraud H., Dupuy A., Moher D., Naudet F. 2020. Data-sharing recommendations in biomedical journals and randomised controlled trials: an audit of journals following the ICMJE recommendations. BMJ Open 10 (5): 1-11.

Singh J. 1991. Understanding the structure of consumers' satisfaction evaluations of service delivery. Journal of the Academy of Marketing Science 19 (3): 223-244.

Song J. H., Zinkhan G. M. 2008. Determinants of perceived Web site interactivity. Journal of Marketing $72(2): 99-113$. 
Sonnier G. P. 2014. The market value for product attribute improvements under price personalization. International Journal of Research in Marketing 31 (2): 168-177.

Steinhoff L., Arli D., Weaven S., Kozlenkova I. V. 2019. Online relationship marketing. Journal of the Academy of Marketing Science 47 (3): 369-393.

Tam K. Y., Ho S. Y. 2006. Understanding the impact of web personalization on user information processing and decision outcomes. MIS Quarterly 30 (4): 865-890.

Trusov M., Bucklin R., Pauwels K. 2009. Estimating the dynamic effects of online word-of-mouth on member growth of internet social networks. Journal of Marketing 73 (5): 90-102.

Turban E., King D., Lee J. K., Liang T.-P., Turban D. C. 2015. Electronic Commerce: A Managerial and Social Networks Perspective. Springer International Publishing.

Van Heerde H., Dinner I., Neslin S. A. 2019. Too far to walk: Using retailer mobile app to engage distant customers. International Journal of Research in Marketing 36 (3): 420-438.

Varaldo R., Marbach G. 1995. The changing consumer in Italy. International Journal of Research in Marketing 12 (5): 467-483.

Verhoef P. C., Lemon K. N., Parasuraman A., Roggeveen A., Tsiros M., Schlesinger L. A. 2009. Customer experience creation: Determinants, dynamics and management strategies. Journal of Retailing 85 (1): 31-41.

Wedel M., Kannan P. K. 2016. Marketing analytics for data-rich environments. Journal of Marketing 80 (6): 97-121.

Yadav M. S., Pavlou P. A. 2014. Marketing in computer-mediated environments: Research synthesis and new directions. Journal of Marketing 78 (1): 20-40.

Zhang J. 2011. The perils of behavior-based personalization. Marketing Science 30 (1): 170-186.

Zhang J., Wedel M. 2009. The effectiveness of customized promotions in online and offline stores. Journal of Marketing Research 46 (2): 190-206.

Contact information

Received: September 15, 2020

Accepted: November 27, 2020

Megi M. Gogua - Postgraduate Student; m.gogua@spbu.ru

Maria M. Smirnova — PhD in Economics; smirnova@gsom.spbu.ru

\section{ПОДХОДЫ К ПЕРСОНАЛИЗАЦИИ \\ НА КАЖДОМ ИЗ ЭТАПОВ ПУТИ ПОТРЕБИТЕЛЯ}

\section{М. М. Гогуа, М. М. Смирнова}

Санкт-Петербургский государственный университет,

Российская Федерация, 199034, Санкт-Петербург, Университетская наб., 7-9

Для цитирования: Gogua M. M., Smirnova M. M. 2020. Revisiting personalization through customer experience journey. Вестник Санкт-Петербургского университета. Менеджмент 19 (4): 430-460. http://doi.org/10.21638/11701/spbu08.2020.402

Фирмы используют персонализацию, для того, чтобы оказать влияние на опыт клиентов в многочисленных точках контакта. Несмотря на исторически схожее развитие исследований персонализации и клиентского опыта, в настоящее время академическая литература в большей степени сконцентрирована на изучении отдельных аспектов данных понятий 
без общего подхода к их интерпретации. В статье систематизируются подходы к оценке реакции клиентов, поведенческих последствий, а также к использованию точек контакта с целью разработки карты предложений по выявлению позитивных и негативных последствий применения персонализации. Данный инструмент очень важен, поскольку фирма должна понимать, как клиенты реагируют на персонализацию, и идентифицировать факторы, появляющиеся на этапах до, во время и после совершения покупок. С теоретической точки зрения это исследование формулирует выводы о позитивных и негативных последствиях персонализации для последующих эмпирических исследований. Выводы работы свидетельствуют о целесообразности использования антропоморфизации, в том числе: интерактивных методов общения на сайтах (посредством чат-ботов и их аналогов); рекомендаций, основанных как на ранней истории поведения конкретного клиента, так и на характеристиках той группы, к которой он принадлежит; а также увеличения количества точек контакта и возрастающей цифровой уязвимости клиента. С управленческой точки зрения в исследовании предлагается комплекс мер, которые необходимо принять, для того чтобы обеспечить позитивные эффекты при работе с клиентами или нивелировать негативные за счет увеличения технологических мощностей, внедрения более точных мер оценки и повышения информационной прозрачности.

Ключевые слова: персонализация, клиентский опыт, путь клиентского опыта, маркетинговые точки контакта, поведение потребителя, антропоморфизация, персональные рекомендации, информационная уязвимость потребителя.

Статья поступила в редакцию 15 сентября 2020 г.

Контактная информация

Статья рекомендована в печать 27 ноября 2020 г.

Гогуа Мэги Мерабовна - аспирант; m.gogua@spbu.ru

Смирнова Мария Михайловна — канд. экон. наук; smirnova@gsom.spbu.ru 
An overview of ABS marketing list based articles on personalization with explicit customer focus

\begin{tabular}{|c|c|c|c|c|c|c|c|c|c|c|c|c|c|c|}
\hline \multirow[b]{2}{*}{ Author(s) } & \multirow[b]{2}{*}{$\begin{array}{l}\text { Personalization } \\
\text { applications } \\
\text { and focus }\end{array}$} & \multirow[b]{2}{*}{$\begin{array}{l}\text { Customer- } \\
\text { related } \\
\text { concepts }\end{array}$} & \multicolumn{5}{|c|}{$\begin{array}{c}\text { Customer's } \\
\text { response }\end{array}$} & \multicolumn{3}{|c|}{$\begin{array}{l}\text { Purchase } \\
\text { stage }\end{array}$} & \multicolumn{4}{|c|}{$\begin{array}{c}\text { Touch point } \\
\text { type } \\
\text { (owned by) }\end{array}$} \\
\hline & & & 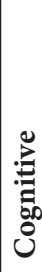 & 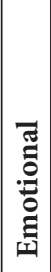 & ڤే: & . & . & 㟒 & 总 & 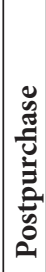 & 包 & 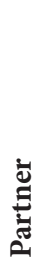 & 离 & 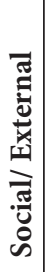 \\
\hline 1 & 2 & 3 & 4 & 5 & 6 & 7 & 8 & 9 & 10 & 11 & 12 & 13 & 14 & 15 \\
\hline $\begin{array}{l}\text { [Meuter et } \\
\text { al., 2000] }\end{array}$ & $\begin{array}{l}\text { Self-service technolo- } \\
\text { gies use for easier service } \\
\text { obtaining }\end{array}$ & $\begin{array}{l}\text { - Customer interac- } \\
\text { tions with techno- } \\
\text { logical interfaces } \\
\text { - Customer-firm } \\
\text { interaction }\end{array}$ & $\mathrm{x}$ & & $\mathrm{x}$ & $\mathrm{x}$ & & & & $\mathrm{x}$ & $\mathrm{x}$ & & & \\
\hline $\begin{array}{l}{[\text { Moon, }} \\
2000]\end{array}$ & $\begin{array}{l}\text { Customer's intimate } \\
\text { information obtaining } \\
\text { through the consumer- } \\
\text { computer context by } \\
\text { scripted communication }\end{array}$ & $\begin{array}{l}\text { - Consumers' self- } \\
\text { disclosure } \\
\text { - Customer vulner- } \\
\text { ability } \\
\text { - Ethics }\end{array}$ & $x$ & $\mathrm{x}$ & & & $\mathrm{x}$ & & & & $\mathrm{x}$ & & & \\
\hline $\begin{array}{l}{[\text { Moon, }} \\
2002]\end{array}$ & $\begin{array}{l}\text { Communication tools } \\
\text { based on message mass } \\
\text { customization based on } \\
\text { style based on the person- } \\
\text { ality types }\end{array}$ & $\begin{array}{l}\text { - Customer com- } \\
\text { munication } \\
- \text { Customer persua- } \\
\text { sion }\end{array}$ & & $\mathrm{x}$ & $\mathrm{x}$ & & $\mathrm{x}$ & $\mathrm{x}$ & & & $x$ & & & \\
\hline $\begin{array}{l}{[\text { Fitzsi- }} \\
\text { mons, } \\
\text { Lehmann, } \\
2004]\end{array}$ & $\begin{array}{l}\text { Impact of recommen- } \\
\text { dations through the } \\
\text { intelligent agents in the } \\
\text { customer decision-mak- } \\
\text { ing and satisfaction }\end{array}$ & $\begin{array}{l}- \text { Customer reac- } \\
\text { tance } \\
- \text { Customer needs } \\
\text { identification } \\
- \text { Consumer re- } \\
\text { sponse } \\
- \text { Customer satisfac- } \\
\text { tion }\end{array}$ & $\mathrm{x}$ & $\mathrm{x}$ & $\mathrm{x}$ & & & $\mathrm{x}$ & $\mathrm{x}$ & $x$ & $\mathrm{x}$ & & & \\
\hline
\end{tabular}


Continuation of the Appendix

\begin{tabular}{|c|c|c|c|c|c|c|c|c|c|c|c|c|c|c|}
\hline 1 & 2 & 3 & 4 & 5 & 6 & 7 & 8 & 9 & 10 & 11 & 12 & 13 & 14 & 15 \\
\hline $\begin{array}{l}\text { [Mont- } \\
\text { gomery et } \\
\text { al., 2004] }\end{array}$ & $\begin{array}{l}\text { Personalization based } \\
\text { on the clickstream data, } \\
\text { that provides informa- } \\
\text { tion about the path (the } \\
\text { sequence of pages) that } \\
\text { the user followed during } \\
\text { the web-site navigation; } \\
\text { it is helpful for predicting } \\
\text { the future movements } \\
\text { at the web-sites (higher } \\
\text { result that the benchmark } \\
\text { purchase conversion pre- } \\
\text { diction rate without path } \\
\text { information) }\end{array}$ & $\begin{array}{l}\text { - Customer web-site } \\
\text { path } \\
\text { - Customer behavior } \\
\text { - Customer inten- } \\
\text { tions }\end{array}$ & & & $\mathrm{x}$ & & & $\mathrm{x}$ & & & $\mathrm{X}$ & & & \\
\hline $\begin{array}{l}\text { [Kramer, } \\
\text { Spolter- } \\
\text { Weisfeld, } \\
\text { Thakkar, } \\
\text { 2007] }\end{array}$ & $\begin{array}{l}\text { Cultural traits of the cus- } \\
\text { tomer (interdependence/ } \\
\text { independence; indi- } \\
\text { vidualistic/collectivistic; } \\
\text { ethnicity) influence on } \\
\text { the customer resoince to } \\
\text { personalization (product } \\
\text { recommendations based } \\
\text { on own preferences or } \\
\text { collective preferences of } \\
\text { similar cultural group) }\end{array}$ & $\begin{array}{l}\text { - Customer's culture } \\
\text { - Customer's re- } \\
\text { sponse to personal- } \\
\text { ization }\end{array}$ & $\mathrm{x}$ & & & & $\mathrm{x}$ & $\mathrm{x}$ & & & $\mathrm{x}$ & & & \\
\hline $\begin{array}{l}\text { [Song, } \\
\text { Zinfhan, } \\
2008]\end{array}$ & $\begin{array}{l}\text { Impact of interactivity } \\
\text { antecedents (number of } \\
\text { clicks, response time, } \\
\text { message types) and level } \\
\text { of personalization in mes- } \\
\text { saging on Web-site inter- } \\
\text { activity and effectiveness }\end{array}$ & $\begin{array}{l}\text { - Customer interac- } \\
\text { tivity } \\
- \text { Customer per- } \\
\text { ceived interactivity }\end{array}$ & $\mathrm{x}$ & & $\mathrm{x}$ & & & $x$ & & $\mathrm{x}$ & $\mathrm{x}$ & & & \\
\hline $\begin{array}{l}\text { [Chung, } \\
\text { Rust, We- } \\
\text { del, 2009] }\end{array}$ & $\begin{array}{l}\text { Personalization in the } \\
\text { digital audio players } \\
\text { through the collaborative } \\
\text { filtering/adaptive system } \\
\text { (as in other personalized } \\
\text { applications) and its im- } \\
\text { pact on the effectiveness } \\
\text { in terms of number of } \\
\text { songs listened to and the } \\
\text { listening duration of the } \\
\text { recommended songs }\end{array}$ & $\begin{array}{l}\text { - Customer prefer- } \\
\text { ences predictions } \\
\text { - Customer behavior } \\
\text { - Customer attitudes }\end{array}$ & $\mathrm{x}$ & & $\mathrm{x}$ & & & & & & $\mathrm{x}$ & & & $\mathrm{x}$ \\
\hline
\end{tabular}


Continuation of the Appendix

\begin{tabular}{|c|c|c|c|c|c|c|c|c|c|c|c|c|c|c|}
\hline 1 & 2 & 3 & 4 & 5 & 6 & 7 & 8 & 9 & 10 & 11 & 12 & 13 & 14 & 15 \\
\hline $\begin{array}{l}{[\text { Franke, }} \\
\text { Keinz, Ste- } \\
\text { ger, 2009] }\end{array}$ & $\begin{array}{l}\text { Use of personalization } \\
\text { tools (smart agents) for } \\
\text { customization benefits }\end{array}$ & $\begin{array}{l}- \text { Customer satisfac- } \\
\text { tion } \\
- \text { Customer interac- } \\
\text { tivity } \\
- \text { Customer prefer- } \\
\text { ences }\end{array}$ & $\mathrm{x}$ & & $\mathrm{x}$ & & & $\mathrm{x}$ & $\mathrm{x}$ & & $x$ & & & \\
\hline $\begin{array}{l}\text { [Zhang, } \\
\text { Wedel, } \\
\text { 2009] }\end{array}$ & $\begin{array}{l}\text { Granularity levels-based } \\
\text { promotions in online and } \\
\text { offline stores includ- } \\
\text { ing the individual-level } \\
\text { personalization }\end{array}$ & $\begin{array}{l}\text { - Customer-cen- } \\
\text { tricity } \\
\text { - Customer loyalty; } \\
\text { - Customer attain- } \\
\text { ment } \\
\text { - Customer attrac- } \\
\text { tion }\end{array}$ & $\mathrm{x}$ & & $\mathrm{x}$ & & & $\mathrm{x}$ & & & $x$ & $x$ & & \\
\hline $\begin{array}{l}\text { [Moreau, } \\
\text { Herd, } \\
2010]\end{array}$ & $\begin{array}{l}\text { Customers' comparisons } \\
\text { of their self-designed } \\
\text { (user-designed) products } \\
\text { with those of others and } \\
\text { experts-recommended }\end{array}$ & $\begin{array}{l}\text { - Customer evalu- } \\
\text { ation of self-de- } \\
\text { signed products } \\
\text { - Customer value- } \\
\text { creation }\end{array}$ & $\mathrm{x}$ & $\mathrm{x}$ & $\mathrm{x}$ & $\mathrm{x}$ & $\mathrm{x}$ & & & $\mathrm{x}$ & & & $\mathrm{x}$ & $\mathrm{x}$ \\
\hline $\begin{array}{l}\text { [Puligadda } \\
\text { et al., } \\
2010]\end{array}$ & $\begin{array}{l}\text { Influence of idiosyn- } \\
\text { cratically evaluated (i.e., } \\
\text { personalizable) attributes } \\
\text { on satisfaction with a } \\
\text { customization platform }\end{array}$ & $\begin{array}{l}\text { - Customer satisfac- } \\
\text { tion } \\
- \text { Customer knowl- } \\
\text { edge } \\
- \text { Customer evalu- } \\
\text { ation }\end{array}$ & $\mathrm{x}$ & $\mathrm{x}$ & $\mathrm{x}$ & & & & & $\mathrm{x}$ & & & $\mathrm{x}$ & $\mathrm{x}$ \\
\hline $\begin{array}{l}\text { [Zhang, } \\
\text { 2011] }\end{array}$ & $\begin{array}{l}\text { Personalized pricing and } \\
\text { its impact on behavior- } \\
\text { based price discrimina- } \\
\text { tion with respect to the } \\
\text { revealed customer prefer- } \\
\text { ences and competition in } \\
\text { the competitive market }\end{array}$ & $\begin{array}{l}\text { - Customer loyalty } \\
\text { - Customer purchase } \\
\text { history } \\
\text { - Customer self- } \\
\text { selection }\end{array}$ & $\mathrm{x}$ & & $\mathrm{x}$ & & & $\mathrm{x}$ & & & $\mathrm{x}$ & & & \\
\hline $\begin{array}{l}\text { [Acquisti, } \\
\text { John, } \\
\text { Loew- } \\
\text { enstein, } \\
\text { 2012] }\end{array}$ & $\begin{array}{l}\text { Trade-offs between } \\
\text { privacy and (for example) } \\
\text { personalization, which } \\
\text { has been described as } \\
\text { the future of interactive } \\
\text { marketing [Deighton, } \\
\text { 1996, p. 173] }\end{array}$ & $\begin{array}{l}\text { - Customer welfare } \\
\text { - Customer disclo- } \\
\text { sure behavior } \\
\text { - Customer vulner- } \\
\text { ability perception } \\
\text { - Customer propen- } \\
\text { sity to disclose }\end{array}$ & $\mathrm{x}$ & $\mathrm{x}$ & $\mathrm{x}$ & & & $\mathrm{x}$ & & & $\mathrm{x}$ & & & \\
\hline
\end{tabular}


Continuation of the Appendix

\begin{tabular}{|c|c|c|c|c|c|c|c|c|c|c|c|c|c|c|}
\hline 1 & 2 & 3 & 4 & 5 & 6 & 7 & 8 & 9 & 10 & 11 & 12 & 13 & 14 & 15 \\
\hline $\begin{array}{l}\text { [Dellaert, } \\
\text { Häubl, } \\
\text { 2012] }\end{array}$ & $\begin{array}{l}\text { Recommendations as a } \\
\text { common form of decision } \\
\text { assistance and its impact } \\
\text { on recommending the } \\
\text { customer the products } \\
\text { with attractive features for } \\
\text { a particular customer, in } \\
\text { contrast with an unas- } \\
\text { sisted search by customer }\end{array}$ & $\begin{array}{l}\text { - Customer search in } \\
\text { "choice mode" } \\
\text { - Customer decision- } \\
\text { making }\end{array}$ & $\mathrm{x}$ & & $\mathrm{x}$ & & & $\mathrm{x}$ & & & $\mathrm{x}$ & & & \\
\hline $\begin{array}{l}\text { [Hennig- } \\
\text { Thurau, } \\
\text { Marchand, } \\
\text { Marx, } \\
\text { 2012] }\end{array}$ & $\begin{array}{l}\text { Recommendation systems } \\
\text { (through adaptive person- } \\
\text { alization systems) impact } \\
\text { on customer choice }\end{array}$ & $\begin{array}{l}\text { - Customer decision- } \\
\text { making } \\
\text { - Customer prefer- } \\
\text { ences } \\
\text { - Customer need } \\
\text { identification }\end{array}$ & $\mathrm{x}$ & $\mathrm{x}$ & $\mathrm{x}$ & $\mathrm{x}$ & $\mathrm{x}$ & $\mathrm{x}$ & & $\mathrm{x}$ & $\mathrm{x}$ & & $\mathrm{x}$ & $\mathrm{x}$ \\
\hline $\begin{array}{l}\text { [Feld et al., } \\
\text { 2013] }\end{array}$ & $\begin{array}{l}\text { Personalizing the e-mails } \\
\text { in direct marketing to } \\
\text { customers thus enhancing } \\
\text { the effectiveness; however, } \\
\text { this result is marginal }\end{array}$ & $\begin{array}{l}\text { - Customer response } \\
\text { behavior }\end{array}$ & & & $\mathrm{x}$ & & & & & & $\mathrm{x}$ & & & \\
\hline $\begin{array}{l}\text { [Lam- } \\
\text { brecht, } \\
\text { Tucker, } \\
\text { 2013] }\end{array}$ & $\begin{array}{l}\text { Specificities of dynamic } \\
\text { retargeting through rec- } \\
\text { ommendation agents in } \\
\text { online advertising }\end{array}$ & $\begin{array}{l}\text { - Customer decision- } \\
\text { making } \\
\text { - Customer choice } \\
\text { - Consumer re- } \\
\text { sponse }\end{array}$ & $\mathrm{x}$ & & $\mathrm{x}$ & & & $\mathrm{x}$ & & $\mathrm{x}$ & & & & \\
\hline $\begin{array}{l}\text { [Sonnier, } \\
\text { 2014] }\end{array}$ & $\begin{array}{l}\text { Personalized pricing for } \\
\text { the customer: "how to } \\
\text { aggregate consumer valu- } \\
\text { ations to assess the overall } \\
\text { profitability of attribute } \\
\text { improvements under } \\
\text { price personalization" (p. } \\
\text { 168) }\end{array}$ & $\begin{array}{l}\text { - Customer attri- } \\
\text { butes } \\
\text { - Customer's product } \\
\text { valuation } \\
\text { - Customer choice } \\
\text { - Customer willing- } \\
\text { ness-to-pay }\end{array}$ & $\mathrm{x}$ & & $\mathrm{x}$ & & & $\mathrm{x}$ & & & $\mathrm{x}$ & & & \\
\hline $\begin{array}{l}\text { [Yadav, } \\
\text { Pavlou, } \\
\text { 2014] }\end{array}$ & $\begin{array}{l}\text { E-mail personalization } \\
\text { for online advertisement } \\
\text { and customer acquisition } \\
\text { and retentions; AR for } \\
\text { products and recommen- } \\
\text { dations for individualized } \\
\text { customer experience }\end{array}$ & $\begin{array}{l}\text { - Customer experi- } \\
\text { ence } \\
\text { - Customer acquisi- } \\
\text { tion } \\
\text { - Customer retention } \\
\text { - Customer satisfac- } \\
\text { tion }\end{array}$ & $\mathrm{x}$ & & $\mathrm{x}$ & & & $\mathrm{x}$ & & $\mathrm{x}$ & $\mathrm{x}$ & & & \\
\hline
\end{tabular}




\begin{tabular}{|c|c|c|c|c|c|c|c|c|c|c|c|c|c|c|}
\hline 1 & 2 & 3 & 4 & 5 & 6 & 7 & 8 & 9 & 10 & 11 & 12 & 13 & 14 & 15 \\
\hline \begin{tabular}{|l|} 
[Aguirre et \\
al., 2015]
\end{tabular} & $\begin{array}{l}\text { Even though the greater } \\
\text { personalization increases } \\
\text { service relevance and } \\
\text { customer adoption, it may } \\
\text { have strong impact on } \\
\text { the customer perceived } \\
\text { vulnerability and hence } \\
\text { decrease adoption rates, } \\
\text { thus creating the person- } \\
\text { alization paradox. This } \\
\text { effect is mitigated if the } \\
\text { data collection is con- } \\
\text { ducted not covertly, and if } \\
\text { the trust-building activi- } \\
\text { ties are accomplished with } \\
\text { the inclusion of other } \\
\text { platforms the customers } \\
\text { trust (but duality with the } \\
\text { incorporation the social } \\
\text { networks information is } \\
\text { recognised) }\end{array}$ & $\begin{array}{l}\text { - Customer vulner- } \\
\text { ability } \\
\text { - Customer privacy } \\
\text { concern } \\
\text { - Customer trust } \\
\text { - Customer loyalty }\end{array}$ & $\mathrm{x}$ & & $\mathrm{x}$ & & & $\mathrm{x}$ & & & $\mathrm{x}$ & $\mathrm{x}$ & $\mathrm{x}$ & \\
\hline \begin{tabular}{|l|} 
[Bleier, \\
Eisenbeiss, \\
$2015]$
\end{tabular} & $\begin{array}{l}\text { The impact of depth and } \\
\text { breadth of ad banner } \\
\text { personalization on the } \\
\text { trust and reactance of the } \\
\text { customer. }\end{array}$ & $\begin{array}{l}\text { - Customer reac- } \\
\text { tance } \\
\text { - Customer privacy } \\
\text { concern } \\
\text { - Customer trust } \\
\text { - Customer attitude }\end{array}$ & $\mathrm{x}$ & & $\mathrm{x}$ & & & $\mathrm{x}$ & & $\mathrm{x}$ & $\mathrm{x}$ & $\mathrm{x}$ & & \\
\hline \begin{tabular}{|l|} 
Fong, \\
Fang, Luo, \\
2015]
\end{tabular} & $\begin{array}{l}\text { Mobile targeting through } \\
\text { the location-targeting } \\
\text { (competitive locational } \\
\text { targeting) for attracting } \\
\text { the customer in close } \\
\text { proximity }\end{array}$ & $\begin{array}{l}\text { - Customer's loca- } \\
\text { tion awareness } \\
\text { - Customer click- } \\
\text { through } \\
-\begin{array}{l}\text { Customer respon- } \\
\text { siveness }\end{array}\end{array}$ & $\mathrm{x}$ & & $\mathrm{x}$ & $\mathrm{x}$ & & $\mathrm{x}$ & $\mathrm{x}$ & $\mathrm{x}$ & & & $\mathrm{x}$ & \\
\hline \begin{tabular}{|l|} 
[Chung, \\
Wedel, \\
Rust, \\
$2016]$
\end{tabular} & $\begin{array}{l}\text { "Repeatedly adapting to } \\
\text { the customer's observed } \\
\text { behavior improves } \\
\text { personalization perfor- } \\
\text { mance"; "personalizing } \\
\text { automatically, using a } \\
\text { personalization algo- } \\
\text { rithm, results in better } \\
\text { performance than allow- } \\
\text { ing the customer to self } \\
\text { customize"; "using the } \\
\text { customer's social network } \\
\text { for personalization results } \\
\text { in further improvement" }\end{array}$ & $\begin{array}{l}\text { - Customer data } \\
\text { - Customer prefer- } \\
\text { ences in offerings } \\
\text { - Customer's social } \\
\text { networks }\end{array}$ & $\mathrm{x}$ & & $\mathrm{x}$ & & & $\mathrm{x}$ & & & $\mathrm{x}$ & & $\mathrm{x}$ & \\
\hline
\end{tabular}


Continuation of the Appendix

\begin{tabular}{|c|c|c|c|c|c|c|c|c|c|c|c|c|c|c|}
\hline 1 & 2 & 3 & 4 & 5 & 6 & 7 & 8 & 9 & 10 & 11 & 12 & 13 & 14 & 15 \\
\hline $\begin{array}{l}\text { [Wedel, } \\
\text { Kannan, } \\
\text { 2016] }\end{array}$ & $\begin{array}{l}\text { Personalization of mar- } \\
\text { keting mix to individual } \\
\text { consumers; online and } \\
\text { mobile personaliza- } \\
\text { tion of marketing mix; } \\
\text { recommendations to the } \\
\text { consumers to fill absent } \\
\text { data; adaptive person- } \\
\text { alization approaches to } \\
\text { learn and adapt to users' } \\
\text { preferences' changes; } \\
\text { evaluation of person- } \\
\text { alization effectiveness } \\
\text { (profitability) }\end{array}$ & $\begin{array}{l}\text { - Capturing custom- } \\
\text { er heterogeneity } \\
\text { - Customer privacy } \\
\text { concern } \\
\text { - Customer data ac- } \\
\text { cumulation }\end{array}$ & $\mathrm{x}$ & & $x$ & & $\mathrm{x}$ & $x$ & $\mathrm{x}$ & $\mathrm{x}$ & $\mathrm{x}$ & $\mathrm{x}$ & & $\mathrm{x}$ \\
\hline $\begin{array}{l}\text { [Martin, } \\
\text { Borah, } \\
\text { Palmatier, } \\
\text { 2017] }\end{array}$ & $\begin{array}{l}\text { Enchancing firm's of- } \\
\text { ferings through the } \\
\text { personalized experience } \\
\text { with a sufficient level of } \\
\text { transparency; duality of } \\
\text { consumer data collection }\end{array}$ & $\begin{array}{l}\text { - Customer percep- } \\
\text { tion of vulner- } \\
\text { ability } \\
\text { - Customer reac- } \\
\text { tance } \\
\text { - Customer data col- } \\
\text { lection } \\
\text { - Customer satisfac- } \\
\text { tion }\end{array}$ & $\mathrm{x}$ & $\mathrm{x}$ & $\mathrm{x}$ & & $\mathrm{x}$ & $x$ & & $\mathrm{x}$ & $\mathrm{x}$ & $\mathrm{x}$ & & \\
\hline $\begin{array}{l}{[\text { Kim, }} \\
\text { Barasz, } \\
\text { John, } \\
\text { 2019] }\end{array}$ & $\begin{array}{l}\text { Personal information } \\
\text { collection for generat- } \\
\text { ing and showing the ad } \\
\text { (behavioral targeting); } \\
\text { information transparency } \\
\text { and changes in its levels } \\
\text { based on the trust to the } \\
\text { platform }\end{array}$ & \begin{tabular}{|l} 
- Customer vulner- \\
ability \\
- Customer privacy \\
concern \\
- Customer need for \\
personalization \\
- Customer loyalty \\
- Customer informa- \\
tion disclosure
\end{tabular} & $\mathrm{x}$ & $\mathrm{x}$ & $\mathrm{x}$ & & & $\mathrm{x}$ & & $\mathrm{x}$ & $\mathrm{x}$ & $\mathrm{x}$ & & \\
\hline $\begin{array}{l}\text { [Kumar, } \\
\text { 2018] }\end{array}$ & $\begin{array}{l}\text { Importance of "machine } \\
\text { learning algorithms used } \\
\text { in areas such as data } \\
\text { security, health care, natu- } \\
\text { ral language processing, } \\
\text { marketing personaliza- } \\
\text { tion, and online recom- } \\
\text { mendations" (p. 6) }\end{array}$ & $\begin{array}{l}\text { - Customer needs } \\
\text { and expectation } \\
\text { reshaping to more } \\
\text { niche }\end{array}$ & $\mathrm{x}$ & & $\mathrm{X}$ & & & & & & $x$ & $\mathrm{X}$ & & \\
\hline
\end{tabular}


End of the Appendix

\begin{tabular}{|c|c|c|c|c|c|c|c|c|c|c|c|c|c|c|}
\hline 1 & 2 & 3 & 4 & 5 & 6 & 7 & 8 & 9 & 10 & 11 & 12 & 13 & 14 & 15 \\
\hline $\begin{array}{l}\text { [Matz et } \\
\text { al., 2019] }\end{array}$ & $\begin{array}{l}\text { Prediction of an image's } \\
\text { personality appeal - the } \\
\text { personality of consumers } \\
\text { to which the advertise- } \\
\text { ment image appeals most }\end{array}$ & \begin{tabular}{|l} 
- Customer emo- \\
tions \\
- Customer attention \\
seeking \\
- Customer first \\
impression; \\
- Customer attitude \\
- Customer purchase \\
intentions
\end{tabular} & $\mathrm{x}$ & $\mathrm{x}$ & $\mathrm{x}$ & & & $\mathrm{x}$ & & & & & & \\
\hline
\end{tabular}

